\title{
Development of mobile phone based agro-advisory system through ICT mediated extension approach in North-eastern himalayan region of India
}

\author{
Biswajit Lahiri $^{1 *}$, Swapnali Borah ${ }^{2}$, Natasha R. Marak ${ }^{3}$ and Thiruchirapalli Sudarshan \\ Anurag 4 \\ ${ }^{1}$ Department of Extension and Communication Management, College of Home Science, Central Agricultural \\ University, Sangsanggre, PO- Dobasipara, Town-Tura, Dist-West Garo Hills- 794005 (Meghalaya), INDIA \\ ${ }^{2}$ Department of Family Resource Management, College of Home Science, Central Agricultural University, \\ Tura, West Garo Hills- 794005 (Meghalaya), INDIA \\ ${ }^{3}$ Department of Foods and Nutrition, College of Home Science, Central Agricultural University, Tura, West Garo \\ Hills- 794005 (Meghalaya), INDIA \\ ${ }^{4}$ Media Lab Asia, Devika Towers, 6 Nehru Place, New Delhi, INDIA \\ *Corresponding author. E-mail: biswajit.lahiri@gmail.com
}

Received: December 6, 2016; Revised received: March 22, 2017; Accepted: August 23, 2017

Abstract: To achieve gainful development in agriculture to ensure food security in the north-eastern Himalayan region of India, an initiative was taken to develop mobile phone based agro-advisory system with the objective to empower the farmers by providing right information at right time through Information and Communication Technology mediated extension approach. 2000 farmers and farm women were selected as beneficiaries through snowball sampling method based on certain criteria. The major features of the system to deliver the farm advices (Pull Based) and information services (Push Based) through toll free Interactive Voice Response System (IVRS), Smart Phone Application, Mobile phone and Web based agriculture advisory system. It was found that on an average almost 200 advisories were provided every month, which even shoot up to almost 300 calls per month in the peak Kharif seasons as bulk of the advisories were provided during the months of May to November as most number of calls from the farmers came during the period. Majority of the advisories were provided on fishery management practices $(17.32 \%)$, source of seed $(9.95 \%)$, livestock management $(9.18 \%)$, disease and pest management of crops (8.75\%), training information $(9.35 \%)$, rural development schemes $(7.76 \%)$ etc. Moreover, the inclusion of need based training component and convergence with different extension functionaries helped to develop an ICT based Stakeholder Interface (Experts-Line Departments-Agripreneurs-Farmers) in the field of agriculture in the region. This alternate extension system also helped to develop better rapport with the farmers and can be replicated in other hilly region of the world.

Keywords: Agricultural information, Agro-advisory system, Interactive information dissemination system, Mobile extension, North-eastern himalayan region

\section{INTRODUCTION}

In an era of liberalization of the economy, modern agriculture can thrive with the access to up to date information by the farming community. Access to the right information at the right time in the right format and from the right source may shift the balance between success and failure of the farmer (Opara, 2008). The information is also a critical input and as important as other key inputs such as credit, seeds, fertilizers and water. Different sources and channels of agriculture information can play important role to meet this requirement (Yadav et al., 2011). Agriculture and farming, information technology, government-all are in the process of change. These socioeconomic, political, and technical changes inevitably impact the institution of agricultural extension and bring pressure on it also to change (Rivera, 2007). Modern agriculture is highly knowledge intensive and requires the support of Information and Communication Technologies (ICT) for planning, decision making and implementation. The internet, mobile phones, television and radio are providing opportunities to connect the people to obtain and disseminate information and to bring in a new revolution in agriculture. Being the second largest populated country in the world, the pressure of food insecurity is always a matter of great worry for the agriculturist in India. In this regard, the relatively less exploited hilly areas can be made a panacea to the problem and the north-eastern Himalayan regions of the country has the real potential to provide additional thrust to boost up the agricultural production in the country. The ever increasing demand for the resources of the population put the pressure on the biological 
resources of the world. The increasing unpredictability of weather and the natural catastrophes in the Himalaya region are clear-cut indicators of marked shift in weather patterns in the region (Kumar and Chopra, 2009). So, an intensive approach towards agricultural development of region is the need of the time. Hence, the coordinated efforts of extension activities for the dissemination of farm information can play a pivotal role. But, agricultural production and productivity always remained a major concern in the region. Like any other hilly region of the world, tough terrain, lack of trained professionals, inadequate funds always create hindrance in gainful development of agriculture in the north-eastern Himalayan region in India. The shifting cultivation (Jhum) is still the most popular pattern cultivation among all the hilly tribes in the region, though in some areas, farmers adopted settled cultivation. Public participation is necessary to integrate ecosystem conservation and rural development. Strengthened support and more sustainable resource management can contribute to strategies as well as for protection of the biological resources and ecosystem (Soni and Ansari, 2017). Further, difficult terrain, mountainous periphery and frequent natural disasters hinder the development of the region. Due to non-availability of improved technological information to the tribal farmers, agriculture exhibits low unstable productivity, which makes food insecurity problem and also poses serious developmental question to the policy makers. Several Information and Communication Technology (ICT) mediated extension approaches have been adopted in different parts of the world. The information through ICTs alone may not create expected development (Obayelu and Ogunlade, 2006, Heeks, 2010, Sudharshan et al., 2012). Along with appropriate agricultural information and knowledge, field demonstrations and forward (farm machinery, manure, seeds) and backward linkages (post-harvest technology and market) need to be facilitated with appropriate public-private partnership between knowledge and other rural advisory service providers for agricultural

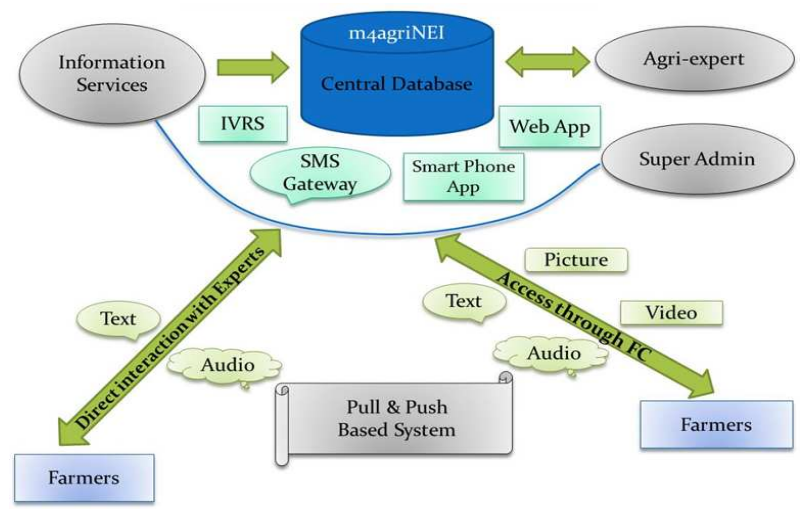

Fig. 1. Agro-advisory system architecture. (Source: Yerapalli et al., 2014) development (Saravanan, 2013). ICTs may supplement rather than replace traditional extension methods as well as that, new roles for extension agents may emerge specifically addressing farmers' needs vis-à-vis IT (Anastasios et al., 2010). The growing popularity, access, use of mobile phone technology and its penetration in all the section of the society in India give a unique opportunity in ICT mediated extension for the development and deployment of mobile phone based agro-advisory system. In this backdrop, an effort has been taken on experimental basis to develop a mobile phone based agro-advisory system in the region with the objective to empower the farmers by providing right information at right time by implementing mobile phone based agricultural extension system.

\section{MATERIALS AND METHODS}

Development of mobile phone based agro-advisory system for the farming communities itself needs careful intervention regarding postulating different component of the system. The reforms of agricultural advisory services can combine different reform elements - such as decentralization, contracting out, using new advisory methods, and changing the management style-in different ways so as to best fit local circumstances. Different contextual factors need to be considered in this regard: the policy environment; the capacity of potential service providers; the type of production systems and market access of farm households; and the characteristics of local communities (Birner et al., 2009). The following components were employed for the development of mobile phone based agro-advisory system for the farming communities in Garo Hills of north-eastern Himalayan region of India.

Establishment of multimedia agro advisory laboratory and connectivity: A multimedia agroadvisory laboratory was developed, which is equipped with state of art information communication tools and gadgets to establish the connectivity through Interactive Voice Response System (IVRS), smart phone and cell phones with farmers and the experts in laboratory. Agro-associates from different disciplines of agricultural sciences, horticultural sciences, animal sciences

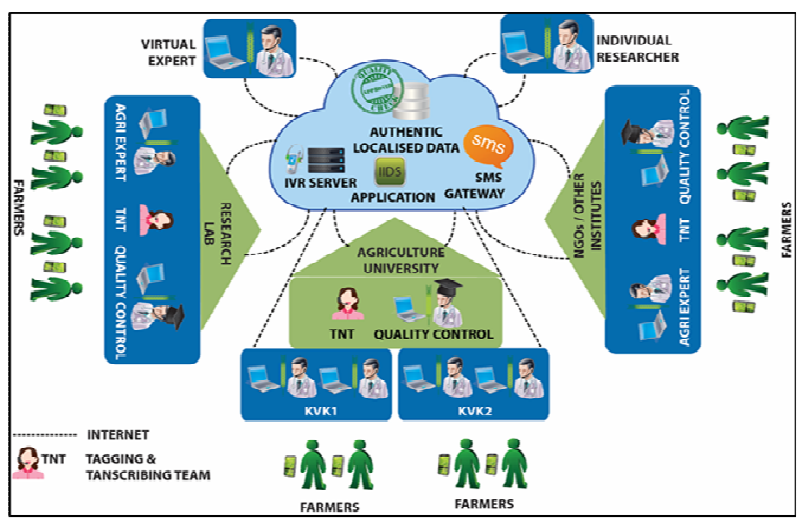

Fig. 2. IIDS Architecture. (Source: Yerrapalli et al, 2014) 
and fisheries sciences were employed, who works as Level-I expert to provide need based advisory services to the farming community. These agro-associates also obtain suggestions and advisory from scientists from different research stations and agricultural university, who are involved as Level-II expert. To develop a link between the farming community and the experts in laboratory, some field coordinators were employed in area-wise taking some villages together. These field coordinators are equipped with smart phone with internet connection and visit a village at least twice in a week to help the farmers, who are not well-versed with cell phone technology, to collect field based problem and send it to the lab, to assess the need of the farming communities, to organize need based training for farming communities etc.

Need assessment and baseline survey: The agricultural information and technological needs of tribal farmers and mobile use pattern were assessed, which served as the basis to design the content for the mobile extension services.

Collection and compilation of localized authentic information on agricultural aspects: Location specific contents on agricultural, horticultural and plantation crops, animal husbandry, fisheries and health and nutrition aspects of villagers were developed / customized by the multidisciplinary team of experts. Multimedia data base was created in local dialects. The voice based advisory services can be accessed both by landline and mobile phones. Smart phones are required to seek advice in multimedia format.

Registration of farmers and their farms, farm animals and fish Ponds: Each farmers has to registered to get the desired services by providing required details (e.g. agri farms, farm animals and fish ponds) to get the advisory services. Similarly to get information service, they have to select the desired information with time and mode of delivery. Each farmer was given a unique ID number and all the transactions and conversation were recorded in the database.

Conducting awareness and training programme for the farmers and farm women: To aware the farming communities regarding the services, to encourage them

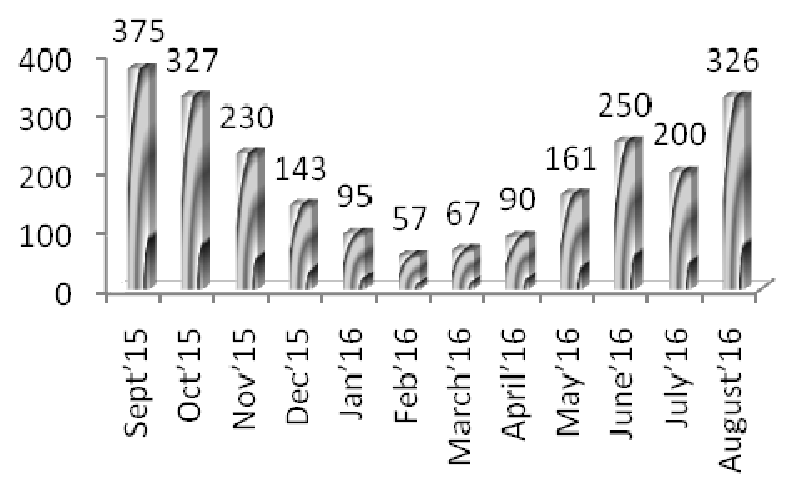

Fig. 3. Month-wise total no. of agro-advisories provided. to take the benefit of project in maximum extent by the beneficiaries; need based training progrmme for the farmers and farm women in the field of agriculture, horticulture, animal sciences, fisheries sciences, maternal and children health and nutrition were conducted.

Delivery of farm advices (Pull Based): To get the advice / information service, the farmers call to the lab through Toll free number, call lands at cloud server. IVRS guides the farmer through recorded menu (in local language). The farmer gets prerecorded location specific information (static and dynamic information) on selected areas. Farmer's queries are answered by the Level-I expert at advisory labs who also record and tag the different types of queries for creation of IVRS database. If the Level-I expert at centre is unable to answer the query, he/ she records the query and transfer to the Level-II experts, who answers the query virtually.

Delivery of information services (Push Based): The system also aggregates location specific data from various reliable information sources (Input Dealers, Financial institutions and IMD, etc.) and disseminate it to the registered farmers depending on the farmers' specified time and mode. These information are aggregated by the system as well as manually by the project staffs. The system architecture has been shown in fig. 1 .

Feedback mechanism: There is also provision of feed -back mechanism in the IVRS system. AgroAssociates are assigned twenty phone numbers each along with farmers' ID number every week, which is randomly generated by IVRS as Call Back option. Agro-Associates call back to those farmers and get the feedback information regarding utility of advisory provided through voice call, text and voice messages, application of training imparted and on issues to get any sorts of hindrance in availing advisories thorugh IVRS. According to the feedback information received, required alternation and modifications in the system, future strategy for agro-advisory services are decided.

The software platform used for this agro-advisory system was 'Interactive Information Dissemination System (IIDS 2.0), which is developed by Media Lab Asia, New Delhi (set-up by Ministry of Electronics and Information Technology, Government of India). IIDS is an integration of Toll free Interactive Voice Response System (IVRS), Smart Phone Application, Mobile phone messaging and Web based agriculture advisory system.

IIDS 2.0 is a pull and push based system where agriculture related information can be pulled by the farmers using the mobile phones. There is a mobile interface at front end and web interface at the back end. Data can be transmitted through voice, text, images and videos from both ends (farmers to expert and back) as shown in fig. 2. This system provides options to farmer to subscribe for the various services. Farmer 


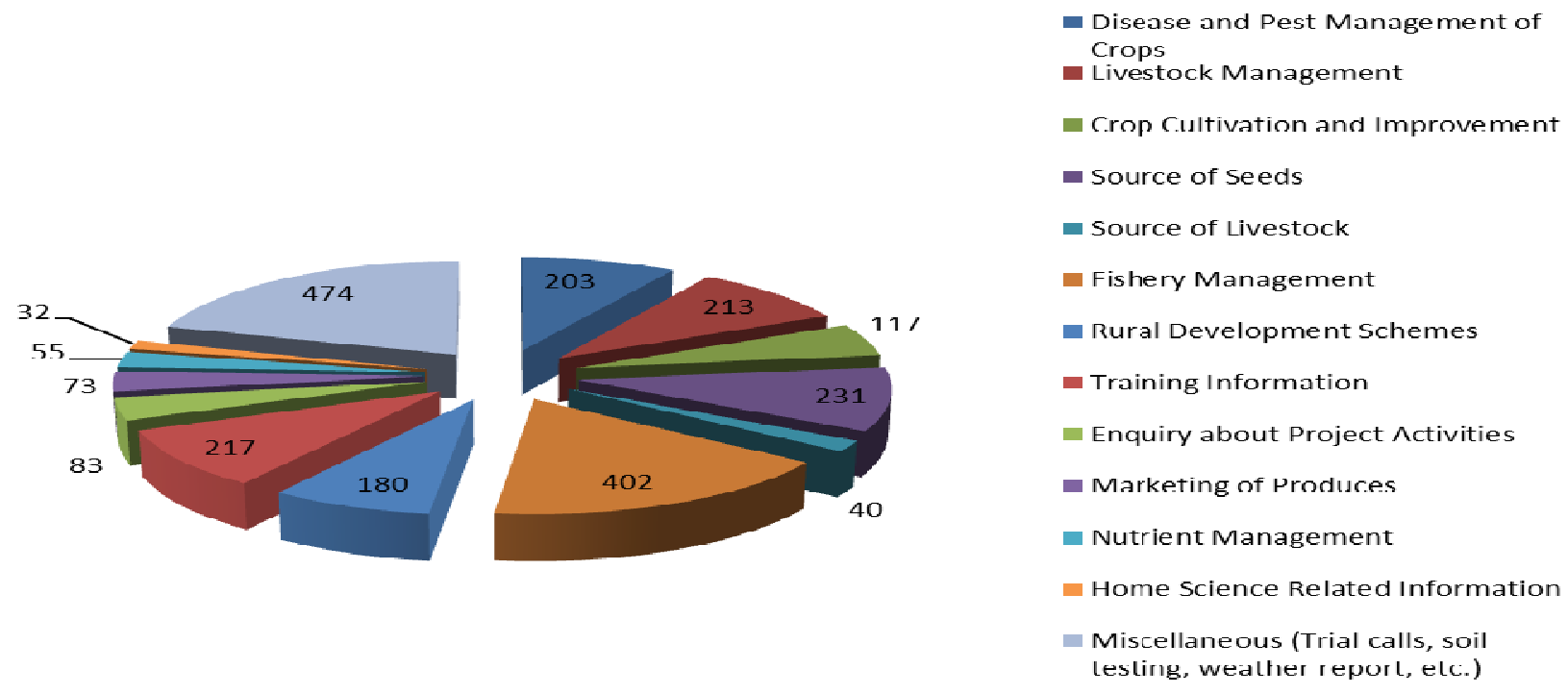

Fig. 4. Distribution of Subject Area-wise Agro-Advisories.

then receives individual needs based information for only those services for which he has subscribed to and has an option at a later date to either select some more services or unsubscribe to some of the existing services. The system is connected to a centralized database, which would have all information of the farm, farmer and previous transactions. The experts at back end (web application) would have access to the database of the farmers while responding to the farmer's queries.

The present study was restricted to the Garo Hills of Meghalaya in the north-eastern Himalayan of India. Out of five districts in Garo Hills of Meghalaya, The West Garo Hills district and South West Garo Hills district were selected through simple random sampling method (Without Replacement). 1000 farmers from 20 villages of West Garo Hills district and 1000 farmers selected from 20 villages of South West Garo Hills district were selected. So, all together 2000 farmers from 40 villages of two districts of Garo Hills were selected through snowball sampling technique. The criteria for selection of villages and farmers were i) availability of mobile phone network in villages, ii) villages should have traditional and settled cultivation, iii) farming is the major sources livelihood, iv) farmers have less accessibility to scientific farming information and v) farmers should have mobile phone connection.

\section{RESULTS AND DISCUSSION}

Pull based advisories: The research work was initiated in July'2015 and to develop mobile phone agroadvisory system an Agro-Advisory laboratory was established, which is equipped with state of art information communication tools and gadgets to establish the connectivity through IVRS, smart phone and cell phones with farmers and the experts in laboratory. At the same time the bench mark survey and need assess- ment of the sample farmers were conducted and the registration of the framers from the field and also in the IIDS 2.0.

The call from the farmers and farm women in the toll free number started from September'2015 and advisories were also provided. The distribution of advisory provided during the period of September'2015 to August'2016 in different subject area is presented in Table 1. From the Fig. 3. it is evident that the bulk of the advisories were provided during the months of May to November as most number of calls from the farmers and farm women came during the period. This is mainly because, the main cropping season in India is Kharif Season (Autumn Cropping), during the period of June-July to September-October, which is initiated with the rains influenced by South-West Monsoon. But, in North-Eastern Himalayan region of Himalaya, pre-monsoon showers starts from the beginning of May and monsoon enters in the last week of May and it continues almost end of October. This part of the world receives highest average rainfall in the world during this period. Farmers in this region cultivate different staple food crops like paddy, maize; summer vegetables, leafy vegetables with the help of monsoon showers in settled cultivation practices. In shifting cultivation (Jhum), farmers usually follow composite farming practices. This is the main reason of receiving more number of calls during this period. Singh et al. (2015) also revealed that highest numbers of the queries were raised through mobile based agro-advisory system in the month of May due to the fact that the month of May is the active growing period for rice, ginger and turmeric crops in Meghalaya. But, after the end of rainy season, dry season starts from November onwards and continues up to April and due to hilly terrains, less water holding capacity of soil and lack of meticulous water conservation infrastructure and policy, water scarcity starts even for potable water. Patle 
and Libang (2014) also reported that temporal variability of seasonal and annual rainfall may affect the agricultural crop production and future water availability in the hilly states of north-eastern region of the country. Thus, most of the arable land in the study area during this period remains fallow due to scarcity of irrigation water. Very negligible areas under low land near Brahmaputra river basin are under cultivation during the period and that is why the number of calls from the farmers and farm women reduced drastically during the period as it is evident from Fig. 3. Choudhury et al. (2012) also reported that rainfalls during the post monsoon season play a significant role in the crop intensification, particularly in rainfed agriculture of north east India.

The distribution subject area-wise call received and advisories provided to the farmers and farm women as depicted in Fig. 4 shows that majority of the advisories were provided on Fishery Management Practices $(17.32 \%)$ and also on Miscellaneous type of information $(20.42 \%)$ like weather related information, soil testing information, trial calls to connect IVRS. In study area, due to heavy downpour during rainy season, lots of small water bodies are created temporarily, which dried up in dry season. Farmers are generally make fish farming in these water bodies during rainy season, which is the main reason for getting more calls on fishery management practices. Besides that other major areas advisories were provided according to call received were source of seed $(9.95 \%)$, livestock management $(9.18 \%)$, disease and pest management of crops $(8.75 \%)$, training information $(9.35 \%)$, rural development schemes (7.76\%) etc. Singh et al. (2015) also found that the highest number of queries on IVRS based agro-advisory was about the seed and its source and it accounted for 32.91 per cent of the total queries, which was followed by crop disease and pest management $(17.08 \%)$ and livestock management (12.36\%).

Pushed based advisories: Rastogi and Hassan, (2014) reported that penetration of mobile phone is more in the areas than the television sets. This might be due to the period of information technology and reasonable cost of mobile phones. To supplement the mobile phone based agro-advisory system and create the demand for information among the registered farmers, need based, location specific and season based text and voice messages were pushed to the farmers. Lahiri et al. (2017) found that most of the Garo tribal farmers $(79.51 \%)$ want information through text messages as it is easy for those who can read text messages and they can keep it as reference information. During the off season, the farmers want information mainly on training $(39.51 \%)$ and farmers feel that training will help to improve their cultivation practices. Thus, a detailed season-wise schedule of text and voice message were prepared and twenty five text message and twenty five voice messages were pushed and Filed Coordinators

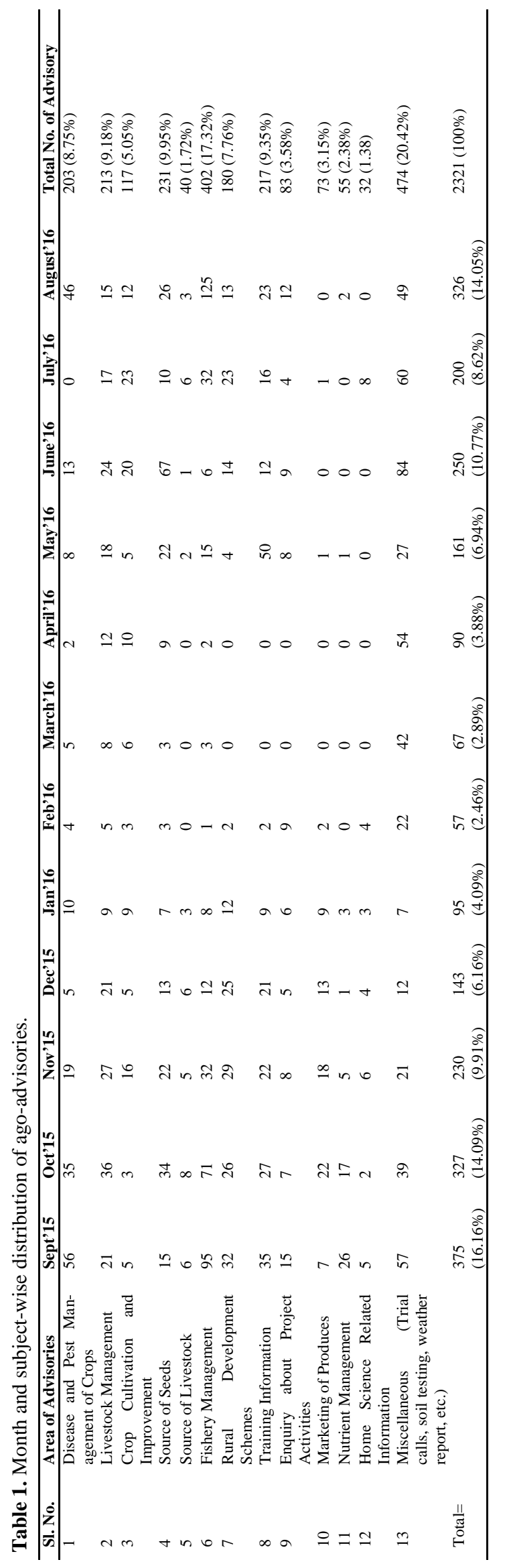


were assigned to get feedback regarding those understanding and utilization of messages by the farmers. Most interestingly, it was found that whenever the messages were pushed, there was considerable increase in number of phone call (on an average $46.7 \%$ ) in the immediate next couple of days as received in the laboratory. Thus, pushed based message service successfully helped to create the demand for information among the farmers.

Moreover, five need based training programme were also conducted, which had been decided according to the training need assessment study done during benchmark survey. These training programmes also helped to sensitize and generate interest among the farmers towards the activities of mobile based agro-advisory system. Besides that, registered farmers were facilitated by the agro-experts to avail different inputs like seeds, bio-fertilizer, organic pesticides, fingerling, vaccination of animals etc. Efforts were also made to make market link-up for the marketing of some specific produces of the registered farmers.

\section{Conclusion}

The initiative was taken to develop an alternate extension system though ICT mediated approach on experimental basis to ensure the food security in the northeastern Himalayan region of India and in the country in general by providing right information at right time to farming communities. The approach was found quite effective in unique situation of the region and satisfactory responses were also found from the farming communities to access and utilize the information. On an average almost 200 calls were received every month from the farmers and advisories were provided, which even shoot up almost 300 calls per month in the peak Kharif seasons. This is very encouraging in terms developing an attitude for seeking scientific farm information from the tradition bound and information poor tribal farmers in the region. The need based push messages also help increase the number of call on an average 46.7 per cent in the immediate next couple of days of pushing message. Moreover, the inclusion of need based training component and convergence with different extension functionaries helped to develop an ICT based Stakeholder Interface (Experts-Line Departments-Agripreneurs-Farmers) in the field of agriculture in the region. This alternate extension system also helped to develop better rapport with the farmers and can be replicated in other hilly region of the world.

\section{ACKNOWLEDGEMENTS}

This research was conducted under m4AgriNEI project, which is undertaken by Central Agricultural University, Imphal, Manipur and Media Lab Asia (setup by Ministry of Electronics \& Information Technology, Government of India), New Delhi.

\section{REFERENCES}

Anastasios, M., Koutsouris, A. and Konstadinos, M. (2010). Information and communication technologies as agricultural extension tools: a survey among farmers in West Macedonia, Greece, The J Agri Edu and Ext. 16 (3) : 249-263

Birner, R., Davis, K., Pender, J., Nkonya, E., Anandajayasekeram, P., Ekboir, J., Mbabu, A., Spielman, D. J., Horna, D., Benin, S. and Cohen, M. (2009). From best practice to best fit: a framework for designing and analyzing pluralistic agricultural advisory services worldwide, The J Agri Edu and Ext. 15 (4) : 341-355

Choudhury, B. U., Das, A., Ngachan S. V., Slong, A., Bordoloi, L. J. and Chowdhury, P. (2012). Trend analysis of long term weather variables in mid altitude Meghalaya, North-East India. J. Agri Physics, 12 (1):12-22

Heeks, R. (2010). Do information and communication technologies (ICTs) contribute to development? J Int Dev. $22(5): 625-640$

Kumar, V. and Chopra, A. K. (2009). Impact of climate change on biodiversity of India with special reference to Himalayan region-An overview. J. Appl. \& Nat. Sci. 1 (1): $117-122$

Lahiri, B., Anurag, S., Chauhan, J. K., Sangma, A. K. and Sangma, S. M. (2017). Mobile phone use efficiency of Garo tribal farmers in north- eastern Himalayan region of India. Indian Res. J. Ext. Edu. 17 (1): 24-31

Obayelu, A. E. and Ogunlade, I. (2006). Analysis of the uses of information and communication technology for gender empowerment and sustainable poverty alleviation in Nigeria. Inter J Edu and Dev. 2 (3): 45-69

Opara, U. N. (2008). Agricultural information sources used by farmers in Imo state, Nigeria. Info Dev. 24 : 289-295

Patle, G. T. and Libang, A. (2014). Trend analysis of annual and seasonal rainfall to climate variability in North-East region of India. J. Appl. \& Nat. Sci. 6 (2): 480-483

Rastogi, S. and Hasan, S. (2014). A study on communication behaviour of agricultural input users of Udham Singh Nagar district of Uttrakhand, India. J. Appl. \& Nat. Sci. 6 (1): 193-196

Rivera, W. M. (2007). Agricultural extension into the next decade. European J Agri Edu and Ext. 4 (1): 29-38.

Saravanan, R. (2013). e-Agriculture prototype for knowledge facilitation among tribal farmers of North-East India: innovations, impact and lessons. The J Agri Edu and Ext.19 (2) : 113-131

Singh, R., Syiem, W., Feroze, S. M., Devarani, L., Ray, L. I. P., Singh, A. K., Singh, N. J. and Anurag, T. S. (2015). Impact assessment of mobile based agro-advisory: a case study of tribal farmers of Ri-Bhoi district of Meghalaya. Agri Econ Res Rev. 28 (Conference Number): $183-187$

Soni, D. K. and Ansari, F. (2017). Climate change and biodiversity; impacts, vulnerability and mitigation in Indian perspective : A review. J. Appl. \& Nat. Sci. 9 (1): $632-$ 638

Sudharshan, D. and Selvamathy, Dhivya. (2012). Finfo1: Web based system for fishermen community planning and development- a prototype. Int J Emerg Tech and Advanced Eng. 2 (1): 198-205

Yadav, B. S., Khan, I. M. and Kumar, M. (2011). Utilization pattern of different sources and channels of agriculture 
Biswajit Lahiri et al. / J. Appl. \& Nat. Sci. 9 (3): 1808 -1814 (2017)

information used by the fenugreek growers. Indian Res $J$ Ext Edu., 11 (1): 44-49

Yerrapalli, B. P., Anurag, T. S. and Porwal, A. (2014). Inter- active information dissemination system (IIDS): Learning and beyond. Technology Corner-Media Lab Asia Newsletter. 2 (4):3-5 